\title{
The Trinity: \\ Paradigm for Mission in the Spirit
}

\author{
A. H. Mathias ZAHNiSER
}

Looking at the Trinity as a model of how God' carries out God's mission in the world contributes to our own attempts to cooperate with God in mission. The convictions implied in the belief in God the Father provide a motivation for mission that can be strong and humble in a pluralistic world. The incarnation, as God's way of communicating, offers the model for mission across cultural boundaries. The Holy Spirit's persistent, pervasive, unobtrusive, but creative and sensitive working toward the values of God's reign represents the mode of a mission which discerns bridgeheads for the Spirit, exalts the person of Christ, and empowers individuals and communities of faith. ${ }^{\text {l }}$

A. H. Mathias Zahniser, a former missionary to Egypt and Emeritus Professor of Christian Mission at Asbury Theological Seminary, Wilmore, Kentucky is a specialist in religious studies and Scholar-in-Residence at Greenville College, Illinois, USA.

1.

Whatever else may be said about the Christian Trinitarian view of God, it certainly has its roots in biblical texts, such as, "So the Word became flesh; he came to dwell among us . ..." (John I:

14), "God was in Christ reconciling the world to himself . . ." (2 Corinthians 5: 19), and, "I

will ask the Father, and he will give you another to be your Advocate, who will be with you forever ... "(John 14: 16). ${ }^{3}$

Limited by cultural and political agendas and encumbered by linguistic and conceptual

demands, the doctrines of the Trinity which emerged from the councils of the church represented attempts to communicate as well as to clarify and to defend the faith. ${ }^{4}$

\footnotetext{
${ }^{1}$ This article originally appeared in the journal, Missiology: An International Review, Vol. XVII, No.1, January 1989, 69-82.

${ }^{2}$ All biblical references are from the New English Bible.

3 Edmund Fortman (1972) concludes that while there is no Trinitarian doctrine in the Synoptic Gospels and Acts, "there are traces of the triadic pattern of Father, Son, and Holy Spirit in both" (14). Paul also has "many triadic texts" and "furnishes much material for the later development of a trinitarian doctrine" (23). Finally, John comes the closest of any New Testament writer to a Trinitarian position (30). "The New Testament writers do not speak in abstract terms of nature, substance, person, relation, circumincession, mission; but they present the ideas that are back of these terms in their own Biblical modes of expression." (33).

4 Bishop Lesslie Newbigin (1964:32) has argued that when the church was seeking to communicate the gospel to the Greco-Roman world, "it was the doctrine of the Trinity which was the key to the whole theological debate." On the other hand, he maintains, that "during the era of 'Christendom' the doctrine of the Trinity has not occupied a comparable place in the thought of Christians." Communication of the gospel to Jews and non-Christian Gentiles was the particular locus of the Christian writers in the East in the later second century. Bishop Newbigin (1978:31), on the other hand, sees mission as "an
} 
Today the task of communicating the gospel across cultural boundaries and barriers involves similar difficulties. For example, people influenced by Islam are comfortable with a wide variety of names for God, many of which like al-Hakim, "the Wise," rely on the shaky basis of human analogy for understanding. ${ }^{5}$ Yet they reject any reference to God as "Father." Communicating the gospel to Muslims, therefore, requires coping with the Trinitarian issue. Whatever our judgments may be about the results in our creeds of the discussions about the Trinity in the early Christian centuries, Christians still have to deal with the Father, the Son, and the Holy Spirit. ${ }^{6}$

One approach to the interpretive task which our beliefs about God require of us is to look at the Trinity as a model of how God carries out mission in the world. Such an approach may open up both for ourselves and for others a deeper understanding of the Trinity and serve to guide our own attempts to cooperate with God in mission.

This essay represents a contribution to Trinitarian thinking as a foundation for mission. It suggests that the convictions implied in the belief in God the Father provide a motivation for mission that can be strong and humble in a pluralistic world. The incarnation is seen as God's way of communicating, a way which identifies with those with whom mutual understanding and reconciliation are sought. And for two major reasons the largest portion of the discussion wrestles with the implications of the conviction that God is Holy Spirit.

acting out of a fundamental belief and, at the same time, a process in which this belief is being constantly reconsidered in the light of the experience of acting it out in every sector of human affairs and in dialogue with every other pattern of thought by which men and women seek to make sense or their lives." That "fundamental belief is embodied in the affirmation that God has revealed himself as Father, Son, and Spirit." See also Leonard Hodgson's Croall Lectures (1943), Charter 7, the theme of which is that "trinitarian theology is an interpretation of trinitarian religion" (176). By "religion" he means how the faith is lived in worship, witness and work.

${ }^{5}$ For a litany of the beautiful names of God see Arthur Jeffery (1962:553-555); the images are predominantly from commerce, governance, and society, rather than from family relationships.

${ }^{6}$ Ironically, Bishop Newbigin (1978:30) guesses that "the working concept of God for most ordinary Christians is ... shaped more by the combination of Greek philosophy and Islamic theology which was powerfully injected into the thought of Christendom at the beginning of the High Middle Ages than by the thought of the fathers of the first four centuries." Twenty years' experience teaching religion to undergraduates in both a state university and a denominational liberal arts college leads me to confirm Newbigin's guess. 
On the one hand, since in a post-colonial world it is neither possible nor proper to supply leadership for newly established mission churches from the missionary churches who have established them, both churches must have confidence in the leadership which emerges within the nascent communities of faith. This in itself puts the post-colonial church in the position of its apostolic counterparts. ${ }^{7}$ Bishop Lesslie Newbigin attributes the extraordinary confidence of the apostolic leaders in the churches they established to the fact that "they are convinced that these new Christians have received the Spirit." Paul's whole method, he claims, rests upon the single conviction "that the Holy Spirit of God is himself the missionary" (1964:66).

On the other hand, the pluralistic setting of most of the world's churches means dialogue with other faith communities and secular value systems. ${ }^{8}$ If the Holy Spirit is God present in the world everywhere, persistently and unobtrusively, but creatively and sensitively, working toward the values of God's reign, then the discernment of the Spirit's activity outside the Christian church altogether becomes crucial for a mission strategy that is relevant to God's own activity. Furthermore, the mission of the church can learn from this attempt to discern the work of the Spirit.

\footnotetext{
7 According to Roland Allen (1962a; 1962b; 1965) Paul's missionary methods featured four significant points of difference from modern methods: (1) Paul trusted the whole responsibility for a nascent Christian community of faith to the local leadership and moved on; (2) he did not establish financial relationships with the new church; (3) new Christians did not lose their status as adults: and (4) Paul did not put leaders trained by himself over the new congregations: the ministry for each church was formed from its own members (cited in Newbigin 1978: 144-145). Newbigin confirms Allen's analysis from his own experience in South India (1978:146). He also cites John V. Taylor's portrayal (1958:45-49) of the establishing of the church in Uganda where "the first converts felt the demand of the gospel upon their consciences in ways which had little connection with the ethical teaching of the missionaries. The latter [missionaries] laid great stress on the necessity for an immediate abandonment of polygamy as the condition for baptism. But in the hearts and consciences of the converts other questions were being raised by the gospel and especially by the teaching and example of Jesus himself. They saw in him a new pattern of behavior calling for humility and for willingness to share the work and the hardship of the poor. They saw that slavery was incompatible with allegiance to Christ, and they found themselves engaged in a deep inner struggle between the 'old man' and the 'new man in Christ' of which the missionary was only dimly aware" (Newbigin 1978: 152-153). Another example of this phenomenon is Vincent Donovan's (2003) experience among the Masai, the 2003 edition enhanced by some excellent essays of tribute. In these cases one is impressed with the imaginative Spirit's working with and beyond the witness of those who come with the gospel.

${ }^{8}$ Newbigin (1978: 212) sees the necessity for the church to take the risk of entering into dialogue with other faiths. Entering into dialogue is the "way by which I can confess Jesus Christ as Lord-Lord over all worlds and Lord over my faith." Only as the church is willing to accept the risk of dialogue can it discern how the "Holy Spirit will take all the treasures of Christ, scattered by the Father's bounty over all the peoples and cultures of mankind, and declare them to the church as the possession of Jesus" (212).
} 


\section{God the Father and the Motivation for Mission without Boundaries}

The confession "I believe in God the Father almighty, creator of heaven and earth" implies that the most fundamental motivation for a mission which would leave out no one at all is the universality of God's parental concern for all creation. ${ }^{9}$ Motivation based on the inclusiveness of God's parental concern for all seems better suited to a pluralistic world than one based on the lostness of those outside the bounded set of baptized Christians.

We live in a pluralistic world of multi-vision and multi-claim. Disparate convictions of ultimate reality and ultimate duty confront each of us. At one end of the spectrum, Orthodox Judaism with its quiet commitment to live under commandment in a community outside of time exerts little or no effort to make converts. On the other end of the continuum, the Mormons missionize systematically and strenuously on a global scale. More and more citizens of this global village must cope with the faith options and life claims of ideologies-from passive humanism to resurgent Islam.

On what basis can Christians make Jesus a live option in a my-way-is-better-than-your-way world without betraying the humility that amounts to the very hallmark of the Savior's own self-expression?

Luke's presentation of Jesus' response to his disciples' enthusiasm at their success in mission represents one of the more moving Trinitarian passages in the Gospels: "At that moment Jesus exulted in the Holy Spirit and said, 'I thank thee, Father, Lord of heaven and earth, for hiding these things from the learned and wise, and revealing them to the simple. Yes, Father, such was thy choice"” (Luke 10:21). ${ }^{10}$

\footnotetext{
${ }^{9}$ We are learning slowly that this formulation does not speak of the maleness of God, for to speak of "God the Mother, almighty creator of heaven and earth" would not significantly alter the importance of the conviction as a motivation for mission without boundaries.

10 The material in Luke 10: 1-20 comes from the source which Matthew and Luke share which is distinct from Mark. Matthew places much of this material with Jesus' commission to the twelve in 9: 37-38 and 10: 7-16 and 40. And Luke in 22: 35 38 refers to a portion of the charge to the seventy as though it had been in the charge to the twelve. Thus, Luke must stress the seventy along with the twelve for some theological reason. It could be to continue the Moses and Elijah theme that Luke has started at the beginning of his central section (9:51-62) (Caird 1963: 144): or, since the Gentile nations in Genesis 10 were
} 
This characteristic and spontaneous enthusiasm of Jesus for the "little ones," the least and the lost, is well-known. It represents a thoroughgoing inclusiveness which is certainly connected with Jesus' radical convictions about God as Father.

It is the universal love of the Creator Father for all his creatures that motivates believers in his Son to go to the ends of the earth sharing the good news. The lostness of the unreached is not the fundamental motivation for reaching out. Rather, the outreach of the one Lord of heaven and earth compels our mission to those who have not heard. "You are lost and we are not" is an affirmation that leads away from identity and humility. "You are loved, as are we, by the Lord of heaven and earth!" is an affirmation without arrogance.

God, whom we call Father, because Jesus did, is the one universal, benevolent, holy, righteous, and creative sovereign of the universe. Muslims testify, "There is no god but God." And Jews pray, "Hear, O Israel, the Lord our God is one." We Christians believe that this one Lord has revealed the divine nature and will in Jesus: "Everything is entrusted to me by my Father; and no one knows who the Son is but the Father, or who the Father is but the Son, and those to whom the Son may choose to reveal him" (Luke 10:22). But the good news is not the exclusiveness of this claim, although such truth must be communicated to those who in rebellion or for convenience reject God's invitation. The good news is that the Lord of heaven and earth has chosen self-revelation not in a way the elite alone can respond to, but in a way open to all.

This is not a universalism rendering global Christian witness superfluous, but a universality which makes such witness necessary. Here is an inclusive love which unlocks spiritual effort, not an exclusive superiority which drives reluctant obligation. It is not "the benighted heathen" on the "mission fields" of

considered by the rabbis to be seventy (or seventy-two as some manuscripts of Luke read), Luke could have been stressing the Gentile mission as well as that to Israel. The Gentile purpose seems closer to the overall purposes of Luke than the Moses reference, and if so, it points to the universality or the Christian's mission. 
the world to whom we "deliver our souls," but the lost among us as well as among those to whom we extend the loving self-giving of the Lord of heaven and earth.

\section{God the Son and the Model for World Evangelization}

"So the Word became flesh; he came to dwell among us" (John 1: 14) seems to say that communication requires identification. Communicators must become one with those to whom they wish to communicate and to be with them. Paul echoes the same insight when he includes a Christian hymn in his Philippian letter:

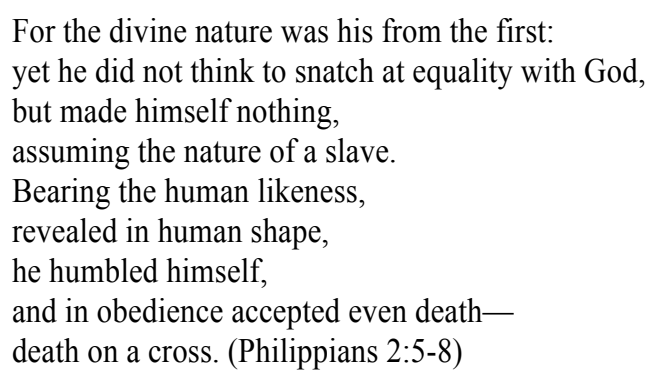

These passages suggest three movements of the Son in communication: 1) self-emptying, 2) identification, and 3) participation. Another Trinitarian passage in Luke focuses upon these movements. In chapter four Luke relates Jesus' temptation in the desert. Jesus, full of the Holy Spirit, is led by the Spirit for a forty-day fast in the desert during which time he is tempted by the devil.

In each temptation the tempter tries to lure Jesus away from his people by stressing his unique privileges and powers as the Messiah: "If you are the Son of God, tell this stone to become bread" (v. 3) "All this dominion will I give to you and the glory that goes with it ... " (v. 6). "If you are the Son of God throw yourself down, for Scripture says ....” (v. 9).

Jesus responds to each challenge by identifying with his people. Each spiritual quotation to which Jesus appeals in his response to the devil he takes from Deuteronomy and Israel's experience in the desert. For example, in the last confrontation the devil quotes Psalm 91, taken to be a messianic promise of invulnerability, tempting Jesus to impress the people with a miraculous ability to emerge unscathed from a 
plunge off the temple pinnacle. Jesus responds with, "You are not to test the Lord your God"

(Deuteronomy 6: 16), a reference to the incident at Massah where Israel challenged God to produce water (Exodus 17:2-7). Jesus refuses to put God in a position where he has to act miraculously to protect his Messiah and salvage his promise.

The whole of the desert temptation of forty days can be seen as an identification of Jesus with his people, Israel, whose forty-year wilderness sojourn was to prepare for mission. As it was in the case of his baptism, it is necessary for Jesus to fulfill all righteousness also in his mission (Matthew 3: 15).

Jesus is full of the Spirit, led by the Spirit, and responsive to the Father's will and word. But he also becomes one with his people, identifying with their trials and obligations. It is just this identification that enables Jesus to return "armed with the power of the Spirit" into Galilee, and to teach in their synagogues, so that everyone "sang his praises" (Luke 414-15).

As we learn more about the nature and force of culture in a society's understanding of reality, it becomes clearer and clearer that communication requires a self-emptying and an identification like that modeled by Jesus. If culture is "the acquired knowledge that human beings use to interpret experience and generate social behavior" (Spradley and McCurdy 1975:5), then all that people have learned is a result of their particular cultural perspectives. Culture binds a society together with a common worldview and common values, mores, institutions, and artifacts. From the abstract to the concrete, all that people believe and do tends to reinforce their view of reality and to bind them together as a people who know, understand, feel, and act in community. But culture also blinds a people to other visions of reality.

The Gospel according to Mark contains a literary unit (8:22-10:52) which illustrates the blinding force of cultural conditioning. The section begins with the healing of a blind man in two stages and ends with the healing of blind Bartimaeus. Within the section marked off by these bookend-like healings, Jesus tries three different times to teach his disciples — who already know he is the Messiah (8:29) - that it is 
necessary for the Son of Man to be humiliated, crucified, and on the third day rise from the dead (8:31-35; 9:31- 36; 10:32-45). His followers have discovered that Jesus is the Messiah, but their culture makes it virtually impossible for them to realize that the Messiah is the Suffering Servant (Isaiah 53).

The disciples' difficulty in understanding is only exceeded by the Master's patience and persistence in teaching them. If such "incarnational communication" was necessary for Jesus, is it any wonder that the reality of culture requires of us a similar self-emptying and identification, a similar patience and persistence in communication? When the work of incarnation has been rigorous, mission in the Spirit is likely to be accomplished.

This is particularly difficult for those of us from American culture to grasp since we are scripted from childhood by superhero myths to believe that experts from outside the community solve our problems for us. Specialists are trained to solve problems that baffle ordinary people, but specialists thorough transformation must empower the community itself.

Jesus, our model for mission, was no Spider Man. We, like him, empty ourselves, identify with the people to whom we wish to communicate, and participate in their privileges and responsibilities.

Fifty years ago I arrived in a land to which I felt called as a missionary with as much of my own way of life in crates as I, with the help of my board, could afford to import. I remember being told that if I wanted good cotton and wool socks I would have to bring them with me. I brought both. But I found a lot of people who were born in that country wearing what looked to me like adequate, if not quality, socks. While Jesus came into the world naked, I arrived with more baggage than did all three of the magi.

When we struggle with language learning and with other difficult adjustments to a worldview and to customs utterly new to us, when we come genuinely to admire life ways that others would change because they are different, when we find ourselves threatened by other religious traditions and the people who live 
by them because they are attractive and genuinely spiritual, when we struggle with caring deeply for those whom we misunderstand and who misunderstand us, when we suffer with the people whom we would urge to acknowledge God's lordship, even when we do it most inadequately and with heavy doses of repentance, we reenact the incarnation of him who was among us as one who serves.

\section{God the Spirit and the Mode of Christian Mission}

What do we mean when we say that we believe in the Holy Spirit? What kind of statement does that make about God and what are its implications for carrying out his mission in the world? That God is spirit suggests among other things that God is at work everywhere and at all times. The Spirit is the persistent, permeating, creative, and often the anonymous presence of God working for the realization of divine outcomes.

If this is true, then John V. Taylor's definition of mission as discerning what the creative Spirit is doing in the world and trying to do it with him $(1972: 37,54)$ makes profound sense.

We see in Jesus a ministry that rejoices in the Spirit because it is sensitive to the Spirit. The Spirit moved Jesus to ecstasy when the seventy "evangelists" returned from their successful mission (Luke 10:21). It looks as though he was joyous because he saw his Father's purposes being fulfilled by ordinary people.

Before he had selected his disciples, Jesus had prayed all night (Luke 6:12). It seems natural to link that night-long session with his struggle over whom to choose. It is the same kind of struggle any person will have who would discern what God is already doing and what he wishes to do in the lives and communities of the people to be reached with the gospel. Who would have thought that God was working through the ordinary people as opposed to the learned and wise? Jesus discovered what the Spirit was doing and did it with the Spirit. The ecstasy of Jesus at the 
fruition or his struggle in the realization of the Father's gracious will (Luke 10:21) is the ecstasy of the servant in mission when in the Spirit the joy of Jesus is realized at the fruition of a similar commitment to the will of the Father.

Jesus' all-night struggle points to something that is often overlooked: God has always been where we are going. Sensitivity to the prior work of his Spirit and attention to the Spirit's agenda comprise the difficult beginnings of all ministry in the mode of the Spirit.

Lesslie Newbigin (1978:65) finds the Spirit central in the outreach of the earliest church as narrated in the book of Acts. The Spirit "brings about the meeting of Philip with the finance minister of Ethiopia (8:26-40), . . prepares Ananias to receive the arch-persecutor Saul as a brother (9: 10-19), . . initiates the first mission to the Gentiles (13:1-2) and guides the missionaries in their journeys (16:7)." And in the experience of Peter's breaking his cherished principles to share the gospel at the home of Cornelius (10:1-20), Newbigin (1978:71) sees a model of what I am calling mission in the mode of the Spirit. "The significant advances in my experience," he says, "have come through happenings of which the story of Peter and Cornelius is a paradigm. In ways of which we have no advance knowledge, God opens the heart of a man or woman to the gospel."

Even though we benefit from God's own self-revelation in Christ, and even though we have the writings of the apostles and their associates, their task of discernment and obedience and the struggle they imply is very much our own, especially in situations such as those that are particularly cross-cultural, ${ }^{11}$ where we have few conceptual and experiential clues to aid us. But

\footnotetext{
11 The more we learn about cross-cultural mission, the more we realize that there is a sense in which all ministry is cross-cultural. Even within North American families, ministry can be to people whose world views are considerably different. What we learn by necessity for typical cross-cultural situations, such as that of a Korean missionary witnessing in Kenya, we would be well advised to learn for ministry in the Spirit in situations that are less obviously cross-cultural such as that of a Korean pastor in Seoul.
} 
we can be comforted by the fact that the Spirit longs to connect persistent activities with the focused revelation of the Father's nature and purpose in the Son-especially as they are revealed in his death and resurrection.

It is liberating to realize with John V. Taylor (1972:3) that "the chief actor in the historic mission of the Christian church is the Holy Spirit." Since creation, the Spirit has been active where we are going preparing for the story of Jesus to be told, explained and exemplified. Therefore, if we are sensitive to what has already been accomplished and to what is now going on, we can assist the Spirit in making connections with what the Father has accomplished in the Son and what the Son has revealed of the Father. As Jesus himself prayed, "This is eternal life: to know thee who alone art truly God, and Jesus Christ whom thou hast sent" (John 17:3).

\section{Characteristics of Mission in the Mode of the Spirit}

This activity of the Spirit which I am describing as the mode of Christian mission can be characterized as patient, permeating, self-effacing activity to connect the purposes of the Father with the person of the Son, and to achieve these purposes everywhere. The Spirit's agenda seems to suggest that cross-cultural mission will be engaged in discerning points of contact, exalting the person of Jesus, and empowering persons through increasing their awareness, widening their horizons of choice, and freeing them for selfgiving.

\section{Discerning Points of Contact}

If we begin our ministry cultivating sensitivity to what the Spirit has already been doing, the fact that the Spirit's work has been distorted by the cultural constraints within which the Spirit has been working creatively will not obscure for us the fact that the Spirit has been at work within the structures of the very mission context to which God has opened the way for us. Therefore, we will be about the business of discerning these bridgeheads of the Spirit as points of contact for the gospel. 
For example, typically, Muslims do not accept that God is spirit. They think of the realm of spirit as a created realm distinct from physical reality, but also distinct from the unique God for whom there is no adequate analogy and who participates neither in the physical nor the spiritual realms of creation. The Spirit working among Muslims may have been working with this reality, sowing seeds of faith that God does engage in the realms of spirit and matter. In situations where resistance would have resulted from proclaiming Jesus as the Son of God, I have discovered interested attention to the suggestion that God desires to participate in the realms of spirit (Holy Spirit) and matter (Jesus). Thus, both the subjects of the incarnation and the Trinity are approached in a new way and can be examined without some of the old conflicts.

The Spirit is also sensitive to the real needs and preoccupations of persons as well as to the realities of a people's worldview. Points of contact need not be doctrinal. Sensitivity and compassion can never be separated in the Spirit. Right in the middle of a dialogue I was having with an international student on some basic religious convictions, I was reminded of the fact that I taught my students to be sensitive to what the Spirit was already doing. I immediately changed tracks in my conversation and discovered that he was deeply troubled about his wife's lengthy illness and with whether or not he should transfer to another engineering program. I was able to discover a Christian couple living in the apartment complex where he lived and asked them to reach out in love and witness to this student and his wife. ${ }^{12}$

Christian witness in the mode of the Spirit means sensitivity to what has already been happening to the person or community to whom witness and ministry are being offered.

\section{Exalting the Person of Jesus Christ}

Olin A. Curtis (1956:502) identifies the "personal peculiarity of each Person in the Trinity. The peculiarity

\footnotetext{
12 A dramatic and well-known example of a point of contact is presented in a case study by Jack Rogers of Fuller Theological Seminary, based on Don Richardson's book Peace Child (1974). Don and Carol Richardson discovered in a peacemaking ceremony between two violently hostile tribes a point of contact for understanding God's own "peace child." See the publication of the case with a variety of theological responses in Evans and Parker (1976: 105-132).
} 
of the Father is that of origination." He is the causal source of the divine organism whose will is original and supreme. To speak of God per se without qualification is to speak of the sovereign Father. The Son is distinguished by the "active, personal, self-assertive obedience" (1956:502)

The personal peculiarity of the divine Spirit, according to Curtis (1956:502, 503), is self-effacement. The Spirit's

obedience is not obedience merely, not loving obedience merely, but personal effacement in obedience. [F] or instance, the Holy Spirit wants nothing for himself. He wants us only to belong to Christ, only to serve Christ, only to love Christ supremely.

The total self-expression of the Spirit of God is service.

I have learned from the Buddhist tradition the truth that a guest room is useful only when it is empty. Emptiness is in itself a kind of fullness. The filling of the Spirit depends on emptiness of agendas of selforientation, ${ }^{13}$ but it is also a metaphor for the sensitivity, freedom, and creativity which enable us to be truly ourselves. To be empty of our own agendas is to be free for the uniqueness that arrives when God is allowed to write the scripts for our lives. This same sensitivity, freedom, and creativity will characterize the ministry, mission, and evangelization of communicators who are open to the pressure and priorities of the self-effacing Spirit. ${ }^{14}$

The Spirit exalts the person of Jesus.

Jesus made clear to disciples saddened by his imminent going to the Father that it was to their advantage that he do so. His explanation for this startling comfort was that the Spirit would "prove the world wrong about sin, righteousness, and judgment" (John 16:8), ${ }^{15}$ wrong about sin in that they did not believe in Jesus, wrong about righteousness because Jesus was going to the Father and they would see

\footnotetext{
13 This is a way of expressing what Paul calls living "according to the flesh" (kata sarka) (Romans 8:5).

14 This is a way of expressing what Paul calls living "according to the Spirit" (kata pneuma) (Romans 8:5).

15 I have used the translation here of Brown (1970:702).
} 
him no more, wrong about judgment because the prince of this world had been judged. It is clear that the person of Jesus Christ is the focus of the Spirit's convincing the world of sin, righteousness, and judgment. Like John the Baptist, the witness in the Spirit confesses, "As he grows greater, I must grow less" (John $3: 30)$.

\section{Empowering Others}

Just as the Spirit is at work seeking points of contact in a mission context for the exaltation of Jesus, so the Spirit is at work in that context seeking to empower people for full conformity to his image (Romans 8:29). That is to say, wherever people are being influenced and shaped in accordance with God's purposes for people's development, one can see the Spirit at work.

Because the activity of the Spirit goes on in and outside of the church, and because the Spirit has been at work in cultures and among communities and individuals who have never heard of God's Son, using all available means to shape people into the image of Christ, theological language and missionary presuppositions may actually hinder our seeing what the Holy Spirit has been doing in a situation. Taylor provides examples of efforts which, because they are not explicitly connected with God's redemptive purposes, might easily go unnoticed by Christian witnesses. Here is one of them:

\footnotetext{
"One thing I advise you to do," said the organization and method man to the management of a chain of city snack-bars, "is to rebuild all your lunch counters on a curve. It will cost you a lot initially, but at a straight counter every customer eats by himself and broods over his troubles. Experiments have shown that if you make them curved even the loneliest man will find himself talking to his neighbour." After a long tussle the organization and method man got his way. (1972:40)
}

Here the person sensitive to the activities God sponsors, activities which contribute to the creation of community and thus to the development of personal awareness, freedom and communal appreciation, will find in this apparently secular event evidence of the anonymous working of God's Spirit.

Julian Rappaport and his associates at the University of Illinois have been demonstrating the positive results of working for the empowerment of persons (Rappaport 1985: 15-21). Rappaport (1985:6) cites 
Ann Weick's analysis (1983:467-471) of the effect on patients of the placebo in medical treatment as evidence of the debilitating effects of the currently dominant medical expert model. When medical doctors administer a placebo, the subtle implication is "that professional treatment is the vehicle for change and that without it good effects cannot be achieved" (Weick 1983:469). The effectiveness of the placebo is in fact due to the capacity of patients to be the source of their own healing.

Rappaport suggests that people in the helping professions should talk in terms of people empowering each other. Empowerment, he admits, is difficult to define. Yet it is clearly missing in people who feel helpless. Empowered people are people with a sense of self-worth, who are able to make a difference in the world around them. Empowerment's absence can be discerned in learned helplessness, a sense of chaos and loss of control. "When the idea of empowerment is combined with the goal of mutuality, mutual empowerment becomes an exciting idea," writes Rappaport (1985:18).

He and his associates have studied an organization, started in Australia, called GROW, which functions as a community of support for individuals considered by professionals seriously mentally ill who, nevertheless, were released from psychological care units. The striking successes of the organization in providing a context for these people to grow in confidence, usefulness, and self-respect suggest that mutual empowerment will provide greater continuing health for former patients than health care administered on the expert-patient model. There is, Rappaport insists, an ethos already afoot in the land which "is not things done to or for people, it is things done with people." This ethos Rappaport (1985: 19) calls the "self-help ethos."

There is scriptural evidence that this kind of empowerment of persons is an important agenda of the Spirit. When people were healed through his ministry, Jesus usually pointed to their own faith as the source of healing — or even the faith of their friends (Mark 2:5). Paul urged the people in his churches to build each other up. Jesus prayed for Christians who would love one another, support one another, and thus be a 
witness to the world. It is not self-help, especially not people helping each other to help themselves, which is anathema to New Testament writers, but self-justification and assumed self-sufficiency. More recently M. Fulgence Nyengele (2014) of the Methodist Theological School in Ohio has brought a significant feature of an indigenous African world view called $\boldsymbol{U} \boldsymbol{b} \boldsymbol{u} \boldsymbol{n} \boldsymbol{t} \boldsymbol{u}$ to contribute a postcolonial and communal model of human well-being to positive psychology. Just a few sentences Nyengele cites the analysis of Ubuntu from Laurenti Magesa, a scholar of African religion who short-titles it "the relationship imperative" (2013: 64). The following couple sentences from Magesa's work will show how the indigenous understanding of God that informs Ubuntu represents a point of contact for a Christian theology of empowerment:

What the African worldview emphasizes ... are relationships. Through the act of creation, God is related in an unbreakable way to the entire universe. At the center of the universe is humanity, but it too is intrinsically and inseparably connected to all living and non-living creation (1997:285286).

The New Testament does not counsel dependence on experts, but interdependence among believers. The enabling of persons for freedom to help each other is high on the agenda of the Spirit. We know this because Jesus released people to dignity, forgiveness, courage, generosity, cooperation, and mutuality. While his contemporaries admired the virtuous, Jesus empowered the rejected; while they rejected sinners, he enabled them to repent; while they legitimized the strong and wealthy, he exalted the weak and poor; while they called the victims of disease sinners, he healed them by engaging their faith, and forgiving their sins; while they saved their reputations, he lost his to save them.

This is ministry in the mode of the Spirit.

Witnesses to the redemptive activity of God in Christ need to be sensitive to situations and movements where the goals of God's kingdom are being realized even if they appear to be unattached to God's specific purposes for saving humankind through Jesus. An empowerment model for the helping professions is a point where those goals are being addressed. Here is a call for discerning the work of the 
Spirit as preparation for the sharing of the gospel. And discerning the activity of the Holy One in that which is at least outwardly secular is not different in kind from discerning that activity among people of other cultures and worldviews. ${ }^{16}$

Whether to people of another culture or to one's family and compatriots, the ministry of mission is to be in the mode of the Spirit- persistent, patient, permeating, self-effacing activity to connect the purposes of the Father with the person of the Son—and to find in the person of the Son the revealed purposes of the Father. We are all called as members of the body of Christ to participate in mission to the world. In this activity the Son provides a model for the preparation for mission with his lavish self-emptying and radical identity with his people, and the Spirit provides a model of the mode for carrying out that mission with sensitivity, self-effacement, and empowerment of others. In other words, the responsibility of people involved in mission is cooperation with the Spirit in order to connect their work with that of the Son so that the Father may be known and obeyed.

\footnotetext{
${ }^{16}$ Kelly S. O'Donnell (1986:213-223) has in fact shown the striking parallels between the goals of community psychology and frontier missions. She reports on the results of using tools common to community psychology to access the receptivity of the great Nahuatl people group in southwestern Mexico. But because the team has apparently looked for sensitivity to the gospel and other cultural realities related to communicating the gospel and not apparently for the impact of the prior or prevenient activity or the Spirit, her results are not reported in these terms.
} 


\section{References Cited}

Allen. Roland

1962a [1912] Missionary Methods: St. Paul's or Ours? Grand Rapids, MI: Eerdmans.

1962b [1927] The Spontaneous Expansion of the Church and the Causes Which Hinder It. Grand Rapids MI: Eerdmans.

1965 The Ministry of the Spirit. Selected Writings of Roland Allen. Rev. ed. David M. Paton, ed. Grand Rapids, M I: Eerdmans.

Brown, Raymond A.

1970 Gospel According to John (xiii-xxi). The Anchor Bible. 29a. Garden City, Y: Doubleday. Caird, G. B.

1963 Saint Luke. Westminster Pelican Commentaries. Philadelphia, PA: Westminster. Curtis, Olin A.

1956 [1905] The Christian Faith: Personally Given in a System of Doctrine. Grand Rapids, MI: Kregel Publications.

Donovan, Vincent J.

2003 Christianity Rediscovered. $25^{\text {th }}$ Anniversary Edition with Interpretive Essays by Nora Koren, Lamin Sanneh and Eugene Hillman. Maryknoll, NY Orbis Books.

Evans, Robert A" and Thomas D. Parker, eds.

1976 Christian Theology: A Case Method Approach. New York: Harper and Row.

Fortman, Edmund

1972 The Triune God: A Historical Study of the Doctrine of the Trinity, Theological Resources. Philadelphia: Westminster.

Hodgson, Leonard

1943 The Doctrine a/the Trinity, Croall Lectures. London: James Nisbet and Co.

Jeffery, Arthur, ed.

1962 A Reader on Islam. The Hague, Netherlands: Mouton and Co.

Magesa, Laurenti. (

2013 What is sacred? African spirituality. New York: Orbis Books.

Newbigin, Lesslie

1964 Trinitarian Faith and Toda y's Mission. Richmond, VA: John Knox Press.

1978 The Open Secret: Sketches for a Missionary Theology. Grand Rapids, M I: Eerdmans.

Nyengele, M. Fulgence

2014 "Cultivating Ubuntu: An African Postcolonial Pastoral Theological Engagement

with Positive Psychology." The Journal of Pastoral Theology 24: 2, Winter: 4-1-35. 
O’Donnell, Kelly S.

1986 "Community Psychology and Unreached Peoples: Applications to Needs and Resource Assessment.” Journal of Psychology and Theology 14:213-223.

Rappaport, Julian

1985 'The Power of Empowerment Language," Social Policy 16: 15-21.

Richardson, Don

1974 Peace Child. Glendale, CA: Regal Press.

Rogers, Jack

1974 "Peace Child" (a case study based on Richardson [1974J and published in Evans and Parker [1976108-112Jl.

Spradley, James P., and David W. McCurdy

1975 Anthropology: The Cultural Perspective. New York: John Wiley and Sons.

Taylor, John V.

1958 The Growth of the Church in Buganda. London: SCM Press.

1972 The Go-Between God: The Holy Spirit and the Christian Mission. New York: Oxford University Press.

Weick, Ann

1983 "Issues in Overturning a Medical Model of Social Work Practice." Social Work 28:467471. 